\title{
Characteristics of sexual violence: Study of 127 cases registered in the Court of Appeals of Cotonou
}

\author{
Bigot Cedric Egnonwa Parfait ${ }^{1, *}$, Adovoekpe Jean Marie², Agbobli Yawo Apelete ${ }^{3}$, Ekouevi Didier ${ }^{4}$, \\ Bigot Andre ${ }^{5}$
}

\begin{abstract}
${ }^{1}$ Assistant Professor, Unit of Forensic Medicine, Faculty of Health Science, University of Abomey-Calavi, Benin, ${ }^{2}$ Assistant Professor, Unit of Forensic Medicine, Faculty of Health Science, University of Parakou, Benin, ${ }^{3}$ Assistant Professor, ${ }^{4}$ Professor,

${ }^{3,4}$ Faculty of Medicine, University of Lome, ${ }^{5}$ Professor, Faculty of Health Sciences, University of Abomey-Calavi, Benin
\end{abstract}

\section{*Corresponding Author:}

Email: bigot.ce@gmail.com

\begin{abstract}
In republic of Benin, rape is a crime for which the law provides harsh penalties. The perpetrators of that form of crime are tried in the courts of appeal by special jurisdictions: the criminal courts. We conducted a case control study on 127 cases of rape investigated and judged by the court of appeal of Cotonou from 2005 to 2015.

This research work points out that victims are exclusively women and girls and that $62.2 \%$ of them are children under 13 years of age. As regards offenders, all of them are male subjects and young adults in $63.8 \%$ of cases. They were acquaintances of the victims in $68.5 \%$ of the cases; and they all confessed to the criminal action with which they were charged. The victims were subject to medical examination 7 times out of 10 without police requisition. Those medical consultations confirmed the presence of injuries caused by extra-genital violence in $\% 18.9$ of victims. Defloration signs were noted in $79.7 \%$ of the girls less than 13 years old.

The populations and health professionals should be sensitized about victims' identification and sociocultural conditions that may facilitate the commission of those crimes; it is an important action to be carried so as to ensure an efficient fight against sexual violence.
\end{abstract}

Keywords: Sexual assault, Rape, Genital injuries, Forensic-medicine, Benin republic.

\section{Introduction}

The World Health Organization (WHO) defines sexual violence as "any sexual act, attempt to obtain a sexual act, unwanted sexual comments or advances, or acts to traffic, or otherwise directed against a person's sexuality using coercion, by any person regardless of their relationship to the victim, in any setting including but not limited to home and work". ${ }^{1}$

It is a public health and human rights issue which affects all countries worldwide. ${ }^{1}$ Women and girls are the first victims. ${ }^{2}$ Studies conducted in different countries point out that one out of three women would have suffered sexual violence. ${ }^{3}$ Sexual violence is often experienced during childhood or adolescence ${ }^{4-6}$ and rape is considered as the most serious form of sexual violence. $^{2}$

In Benin, the criminal code defines rape as "any act of vaginal penetration, anal intercourse or oral penetration by another person's sex or vaginal penetration or anal intercourse by any kind of object without the free and informed consent of the penetrated person." "7 The same code specifies that rape is classified as a crime and must therefore be tried or heard in a special criminal court.

There are few data available on the judicial management of rape in Benin, reason why this study is carried out in order to discuss the epidemiological aspects of rape cases investigated and heard in the Court of Appeals of Cotonou and analyze the conditions under which forensic examination was performed as well as its findings.

\section{Patients and Methods}

This research work was a cross-sectional study with descriptive and analytical purpose. It focused on all the rape cases deferred to the Court of Appeals of Cotonou from 2005 to 2015.

The subjects were recruited based on nonprobabilistic sampling. We took stock of all the rape cases heard during the study period and for which a physical copy was available in the archives.

A data collection form has been drafted taking into account the study objectives. The information related to the profile of victims (age and sex), their aggressors, and to their relationships were registered therein. Information on the circumstances of aggression occurrence (time schedule, number of aggressors, nature of assault and sexual contacts) and forensic observations was collected. The data above were retrieved from the documents included in the indictment file (medical certificate, forensic examination report, minutes of hearing of the different parties, medical record, health book, forensic psychiatric report of the alleged offender).

The data collected have been entered and analyzed using Info 7.1.3.3 version of EPI software. The quantitative variables were presented as averages with their standard deviation and frequencies; and qualitative variables as ratios with their frequency.

Then, we carried out bivariate analyses using $\mathrm{Chi}^{2}$ or Fisher tests to compare qualitative variables according to their applicability requirements. Test was significant if $\mathrm{p}$ was lower than 0.05 . 
This research work was authorized by the presiding judge of the Court of Appeals of Cotonou and submitted to the approval of the ethics committee of the Faculty of Health Sciences in Cotonou. Anonymity and confidentiality were guaranteed.

\section{Results}

A total of 127 prosecution files related to rape were registered i.e. an average of $12 \pm 4$ cases per year.

Sociodemographic characteristics of victims

All the victims were women and girls. Table 1 outlines the sociodemographic characteristics of the victims. Victims' age varied between 3 and 37 years, with an average of $14 \pm 6$ years. Among the victims $62.2 \%$ were minors under 13 years of age and $95.3 \%$ of those victims were Benin nationals. The victims with foreign nationality were Togolese $(n=4)$ and Nigerian $(n=2)$. Most victims $(81.9 \%)$ lived in suburban or rural areas.

Profile of Aggressors: Table 2 describes sexual aggressors' characteristics. We identified 136 aggressors. They were exclusively male. Their ages ranged from 17 to 62 years, with mean age equivalent to $34 \pm 12$ years. Most of them exerted activities related to agricultural production, transportation and trade. Among the aggressors they were nine teachers and four clerics. All of them (100\%) acknowledged during the criminal investigation that they made attempts or had sex with the victims.

Context of Sexual Assaults: Most sexual assaults involved single aggressors (93.7\%). We registered 7 cases involving 2 aggressors and 1 case with 3 aggressors. In $68.5 \%$ of cases, the aggressors were known to their victim and in $11.0 \%$ of the cases; they belong to the victim's family (father-in-law, guardian, uncle or cousin).

Most assaults happened during the day between 6 am and $6 \mathrm{pm}(61.4 \%)$. In $85.8 \%$ of cases, they happened in an enclosed area (residence, house, apartment or workshop). In $25.2 \%$ of cases, sexual aggression took place in the residence of the sex predator. Table 3 shows the distribution of victims according to their age and circumstances surrounding the sexual aggressions. There was a statistically significant relationship between victim's age and time of perpetration of assault $(\mathrm{p}=0.006)$, occurrence of sexual assault in an enclosed area $(\mathrm{p}=0.017)$ and occurrence of sexual assault in the residence of the aggressor $(\mathrm{p}=0.027)$.

Child sexual abuse often happened during the day (between $6 \mathrm{am}$ and $18 \mathrm{pm}$ ). Sexual assaults against adult women often happened in non-enclosed areas (backyards, construction sites, road sides) and rarely in the residence of the predator.

Nature of Sexual Assault: All the victims reported a sexual contact. Most common modalities of sexual contact were genital-to-genital contact $(82.5 \%)$ and digital-to-vaginal sex $(11.4 \%)$. We did not register any case of genital-anal contact attempt. Aggressors were armed (bladed weapon and blunt object) in $22.1 \%$ of cases. The use of weapons was most common in adult victims. We registered two cases of date rape drug through use of alcoholic drinks.

Conditions of Conduct of Forensic Examinations and Observations: Forensic consultations were mostly conducted without police request in $71.9 \%$ of cases. Table 4 specifies the conditions under which forensic consultations were performed (type of entity in charge of management and examiner profile) as well as their outcomes. Seventeen medical certificates have been issued by nurses and midwives. There were exclusively cases of sexual aggression which took place in rural areas.

Hymen injuries were reported in 90 (70.9\%) victims. They were old and recent hymen injuries, respectively in $55(43.3 \%)$ and $35(27.6 \%)$ women. Only 16 minor girls still had their hymen intact.

The medical examiners reported the existence of injuries associated with extra-genital violence in 24 $(18.9 \%)$ victims. Those injuries were wounds $(3.9 \%)$, contusion $(7.1 \%)$ and abrasion $(12.6 \%)$. Extra-genital injuries occurred more often in victims over 13 years of age.

The psychological impact of sexual assaults was addressed in three 3 medical records. Medical examiners mentioned a post traumatic stress syndrome.

\section{Discussion}

This is the first study focused on sexual violence; it was conducted based on criminal cases investigated and heard at the Court of Appeals of Cotonou. The profiles of victims and aggressors were described; the same applies to the circumstances surrounding violence acts. We registered 127 cases. Most victims were minor girls. As regards the aggressors, most of them were male young adults acting alone.

127 case records have been registered in this research work. This number seems to be relatively low for the study period lasted 10 years. This situation may be due to the existence of social barriers which have restrained for a long time the actual criminalization of rapes. The first reason is victims' low inclination to lodge a complaint. Indeed, a study conducted in Tanzania $^{8}$ unveils that African rural and urban populations have a low level of knowledge in matters of sexual violence and tend to be conciliatory when it happens. This study also placed an emphasis on the importance of sensitization towards health workers. Health workers' awareness induces an increased rate of sexual violence reporting. ${ }^{9}$ The second reason is related to police officials. When cases are submitted to them, they endure a lot of pressures from the community which lead them to not refer to court this criminal offence that is rape. They take the position of conciliator, even of judge and incite victims' families to go for amicable settlement, far away from the courts. 
Eventually, the judicial authorities have a certain tendency to refer rape cases to correctional courts by preferentially re-characterizing them as "indecent assault", an offence likely to be judged by magistrate courts. Therefore, they may be subject to penalties lower than when the case is heard before a special criminal court. This situation is not exclusive to Benin. In South Africa, only $10.6 \%$ of cases of adult rapes and $18.1 \%$ of child abuse were heard and tried before a special criminal court. ${ }^{10}$

In our research work, the victims were exclusively female. All the studies point out that sexual violence affects more women than men ${ }^{1,4,11-13}$ In case of child sexual abuse, girls would be 2 to 3 times more exposed than boys. ${ }^{14}$ In the western literature, man/woman sex ratio reported is about $1.5 / 3$ in case of violence against minors. ${ }^{15}$

Nearly $2 / 3$ of sexual violence cases we analyzed were about children under 13 years of age. Similar observations have been made in Port Gentil (Gabon) in a study covering the period running from 2003 to 2006 . 11-15 years age group was the group most exposed to sexual violences, with a frequency estimated at $66 \% .{ }^{16}$ In Benin, justice is not lenient at all in punishing sexual predators when victims are below 16 years of age. The perpetrators of such a type of violence find themselves more easily before the criminal courts since they cannot claim to have obtained the victim's consent. For instance, since $2012,{ }^{7}$ it has been ordained that a female adolescent under 16 years old could not consent to sexual activity.

In Benin, perpetrators of sexual assault were all male subjects. Similar observations have been made in other studies, especially in Senegal, ${ }^{11}$ Gabon, ${ }^{16}$ Guinea, ${ }^{17}$ Brazil, ${ }^{18}$ Turkey, ${ }^{9}$ and in France. ${ }^{19}$ Most perpetrators of sexual assaults are young adults. In our cohort, aggressors' mean age was 34 years versus 29 years in Gabon. ${ }^{16}$ A study conducted in Conakry has proved that sexual violence perpetrators less than 16 years of age accounted for $5 \%$ of people prosecuted for sexual assault. ${ }^{17}$ In this same study, most perpetrators of sexual violence were single men exerting low-paying jobs. Another research work carried out in Guinea has also reported that teachers, clerics, policemen and soldiers were perpetrator of sexual violence. ${ }^{17}$ This profile was not common in our study.

In our series, most sexual assaults were perpetrated by only one aggressor. This remark agrees with the observations made by Niang ${ }^{11}$ in Senegal. By contrast, in countries such as South Africa, a higher rate of gang rape is noted. ${ }^{20}$

In most cases, the victims knew their aggressors. This remark agrees with literature data ${ }^{13,19,20}$ In our research work, $57.5 \%$ of the victims knew their aggressors and the latter were from the family circle, neighborhood or educational environment. Those aggressors were people whose profile confer them a certain authority; therefore this could easily help them to win their victims' trust. In studies conducted respectively in $\mathrm{Togo}^{21}$ and in Senegal, ${ }^{22}$ aggressors were close relatives of the victim at higher rates ranging from $65 \%$ to $73 \%$ of cases. As aggressors are close relatives in the family circle, $1.6 \%$ of assaults were incest sexual offences. The practice heavily repressed by society is generally ignored for community is concerned about preserving the family equilibrium. This intra-family character of child sexual abuses makes their management complex. ${ }^{24}$

Sexual assaults against children less than 13 years of age happened in $72.2 \%$ of cases during the day, in the residence of the aggressor (32.9\%) or near the child's residence $(62.0 \%)$. Therefore, child sexual abuse took place in an environment where minor victim felt very confident. ${ }^{23}$ It also happened at times when children were not under close parental supervision.

The use of edged weapon was more common in aggressors of victims above 13 years of age. Actually, the older the child is, the less common use of physical restraint is. In our study, perpetrator of sexual violence used weapons in only $32.1 \%$ of cases whereas extragenital personal injury was observed in only $11.8 \%$ of victims. Weapons are thus used as means of threat. The extreme fear generated by threat inhibits child victims' resistance and thus pressure them to not resist. This explains the low prevalence of injuries resulting from extragenital physical violence in minors. The adults who are more likely to resist in case of violence often presented with injuries caused by extragenital physical violence in defense areas. The presence of extra-genital physical injuries is a substantial evidence of nonconsent in sexual crime cases among adults.

In criminal matters, the procedure requires that forensic examination be performed upon request of the police. This situation is less common in our cohort or that procedure was followed only in one quarter of the cases. The victims are therefore obliged to finance the medical and legal management of the damage experienced. This situation may be an obstacle to prosecutions, particularly when victims come from an underprivileged socioeconomic background. A similar remark has been made in a study conducted in Gabon. ${ }^{16}$

As side-effects of violence, injuries were observed in one third of the victims. Among female minors and adolescents, most injuries were located in the genital area, whereas among adult subjects, they were located in the rest of their body. Similar observations have been described by Blake in South Africa. ${ }^{25}$

The archives available in the court were not specific to judgments. It would have been helpful to have the opportunity to check if there is a relationship between presence of injury and court ruling. 
Table 1: Distribution of victims according to their age and sociodemographic characteristics

\begin{tabular}{|l|c|c|c|c|c|c|c|c|c|}
\hline & \multicolumn{2}{|c|}{ Total $(\mathbf{n = 1 2 7})$} & \multicolumn{2}{c|}{ Minor $(\mathbf{n = 7 9})$} & \multicolumn{2}{|c|}{ Adolescents $(\mathbf{n = 3 1})$} & \multicolumn{2}{c|}{ Adults (n=17) } & P \\
\hline Characteristics & $\mathrm{N}$ & $\%$ & $\mathrm{~N}$ & $\%$ & $\mathrm{~N}$ & $\%$ & $\mathrm{~N}$ & $\%$ & \\
\hline Place of residence & & & & & & & & & \\
\hline Urban area & 21 & 16.5 & 13 & 16.5 & 5 & 16.1 & 3 & 17.6 & 0.91 \\
\hline Suburban area & 54 & 42.5 & 27 & 34.2 & 19 & 61.3 & 8 & 47.1 & \\
\hline Rural area & 52 & 40.9 & 39 & 49.4 & 7 & 22.6 & 6 & 35.3 & \\
\hline Total & 127 & 100.0 & 79 & 100.0 & 31 & 100.0 & 17 & 100.0 & \\
\hline Nationality & & & & & & & & & \\
\hline Benin National & 121 & 95.3 & 76 & 96.2 & 30 & 96.8 & 15 & 88.2 & 0.34 \\
\hline Foreign National & 6 & 4.7 & 3 & 3.8 & 1 & 3.2 & 2 & 11.8 & \\
\hline Total & 127 & 100.0 & 79 & 100.0 & 31 & 100.0 & 17 & 100.0 & \\
\hline
\end{tabular}

*Minor: Age less than 13 years, Adolescent: from 13 to 17 years old Adults: above 18 years

Table 2: Profile of offenders

\begin{tabular}{|c|c|c|}
\hline & $\mathrm{N}$ & $\%$ \\
\hline \multicolumn{2}{|l|}{ Characteristics } & \\
\hline \multicolumn{3}{|l|}{ Assault by an aggressor acting alone $(n=127)$} \\
\hline Yes & 119 & 93.7 \\
\hline No & 8 & 6.3 \\
\hline \multicolumn{3}{|l|}{ Age of the offender $(n=136)$} \\
\hline$\leq 18$ years & 20 & 15.7 \\
\hline $18-44$ years & 81 & 63.8 \\
\hline$\geq 45$ years & 35 & 27.6 \\
\hline \multicolumn{3}{|l|}{ Civil status of offenders $(n=136)$} \\
\hline Living in a couple at the time of the commission of the assault & 94 & 69.1 \\
\hline Single & 42 & 30.9 \\
\hline \multicolumn{3}{|l|}{ Origin of the offender $(n=136)$} \\
\hline Unknown & 49 & 38.6 \\
\hline Member of the community & 73 & 57.5 \\
\hline Member of the community and family circle & 14 & 11.0 \\
\hline
\end{tabular}

Table 3: Distribution of victims according to their age and context of sexual assault

\begin{tabular}{|l|c|c|c|c|c|c|c|c|c|}
\hline & \multicolumn{2}{|c|}{$\begin{array}{c}\text { Total } \\
(\mathbf{n = 1 2 7})\end{array}$} & \multicolumn{2}{c|}{ Minor (n=79) } & \multicolumn{2}{|c|}{ Adolescents (n=31) } & \multicolumn{2}{c|}{ Adults (n=17) } & p \\
\hline \multicolumn{1}{|c|}{ Characteristics } & $\mathrm{N}$ & $\%$ & $\mathrm{~N}$ & $\%$ & $\mathrm{~N}$ & $\%$ & $\mathrm{~N}$ & $\%$ & \\
\hline $\begin{array}{l}\text { Assault occurred during } \\
\text { the day }\end{array}$ & 78 & 61.4 & 57 & 72.2 & 13 & 41.9 & 8 & 47.1 & 0.006 \\
\hline $\begin{array}{l}\text { Assault occurred in a } \\
\text { private premise }\end{array}$ & 109 & 85.8 & 72 & 91.1 & 26 & 83.9 & 11 & 64.7 & 0.017 \\
\hline $\begin{array}{l}\text { Assault occurred in the } \\
\text { residence of the assailant }\end{array}$ & 32 & 25.2 & 26 & 32.9 & 5 & 16.1 & 1 & 5.9 & 0.027 \\
\hline $\begin{array}{l}\text { Assault occurred near the } \\
\text { residence of the victim }\end{array}$ & 72 & 56.7 & 49 & 62.0 & 13 & 41.9 & 10 & 58.8 & 0.157 \\
\hline
\end{tabular}

*Minor: Age less than 13 years, Adolescent: from 13 to 17 years old Adults: above 18 years

Table 4: Quality of the medical doctors who performed the examination and clinical examination data

\begin{tabular}{|c|c|c|c|c|c|c|c|c|c|}
\hline \multirow[b]{2}{*}{ Characteristics } & \multicolumn{2}{|c|}{$\begin{array}{c}\text { Total } \\
(n=127)\end{array}$} & \multicolumn{2}{|c|}{$\operatorname{Minor}(\mathbf{n}=79)$} & \multicolumn{2}{|c|}{$\begin{array}{c}\text { Adolescents } \\
(\mathbf{n}=31)\end{array}$} & \multicolumn{2}{|c|}{ Adults $(n=17)$} & \multirow[b]{2}{*}{$\mathrm{p}$} \\
\hline & $\mathrm{N}$ & $\%$ & $\mathrm{~N}$ & $\%$ & $\mathrm{~N}$ & $\%$ & $\mathrm{~N}$ & $\%$ & \\
\hline \multicolumn{10}{|c|}{ Conditions of conduct of forensic examination } \\
\hline $\begin{array}{l}\text { Examination carried out within the } 72 \\
\text { hours following the sexual assault }\end{array}$ & 41 & 32.3 & 28 & 35.4 & 9 & 29.0 & 4 & 23.5 & 0.571 \\
\hline
\end{tabular}




\begin{tabular}{|l|c|c|c|c|c|c|c|c|c|}
\hline $\begin{array}{l}\text { Examination done by a general } \\
\text { practitioner }\end{array}$ & 35 & 27.6 & 17 & 21.5 & 10 & 32.3 & 8 & 47.1 & 0.081 \\
\hline Examination done by a Gynecologist & 72 & 56.7 & 50 & 63.3 & 14 & 45.2 & 8 & 47.1 & 0.155 \\
\hline $\begin{array}{l}\text { Examination done in a public health } \\
\text { center }\end{array}$ & 103 & 81.1 & 68 & 60.7 & 21 & 67.7 & 14 & 82.4 & 0.086 \\
\hline Clinical examination data & 95 & 74.8 & 67 & 84.8 & 21 & 67.7 & 7 & 41.2 & 0.001 \\
\hline $\begin{array}{l}\text { Presence of injuries due to violence } \\
\text { in the genital area }\end{array}$ & 55 & 43.3 & 46 & 58.2 & 8 & 25.8 & 1 & 5.9 & \\
\hline Presence of recent hymenal injuries & 35 & 27.6 & 17 & 21.5 & 12 & 38.7 & 6 & 41.2 & \\
\hline Presence of old hymenal injuries & 24 & 18.9 & 8 & 10.1 & 12 & 38.7 & 4 & 23.5 & 0.002 \\
\hline $\begin{array}{l}\text { Presence of extra-genital injuries } \\
\text { caused by violence }\end{array}$ & & & & & & & & & \\
\hline
\end{tabular}

*Minor: Age less than 13 years, Adolescent: from 13 to 17 years old Adults: above 18 years

\section{Conclusion}

Regardless of its target, sexual violence is a public health issue for it has a real negative impact on the individual and the community with psychological effects for life. This study confirms the existence of sexual violence in Benin. It affects women to a great extent and most aggressors are men. The judicial system imposes more severe penalties on perpetrator of child rape or sexual abuse. Forensic and medical management of victims shall be performed as far as possible in a multidisciplinary framework that brings together medical doctors, psychologists and social workers.

Competing Interests: The authors declare that they have no competing interests.

Author's Contributions: All authors read and approved the final manuscript.

\section{References}

1. García-Moreno C, Pallitto C, Devries K, Stöckl H, Watts $\mathrm{C}$, Abrahams N. Global and regional estimates of violence against women: prevalence and health effects of intimate partner violence and non-partner sexual violence. Geneva, Switzerland: World Health Organization; 2013. $50 \mathrm{p}$.

2. Dartnall E, Jewkes R. Sexual violence against women: the scope of the problem. Best Pract Res Clin Obstet Gynaecol. 2013;27(1):3-13.

3. Kirk L, Terry S, Lokuge K, Watterson JL. Effectiveness of secondary and tertiary prevention for violence against women in low and low-middle income countries: a systematic review. BMC Public Health. 2017;17(1):6-22.

4. Pereda N, Guilera G, Forns M, Gómez-Benito J. The prevalence of child sexual abuse in community and student samples: a meta-analysis. Clin Psychol Rev. 2009;29(4):328-38.

5. Mellins CA, Walsh K, Sarvet AL, Wall M, Gilbert L, Santelli JS, et al. Sexual assault incidents among college undergraduates: Prevalence and factors associated with risk. PloS One. 2017;12(11):01864-71.

6. Adinew YM, Hagos MA. Sexual violence against female university students in Ethiopia. BMC Int Health Hum Rights. 2017;17(1):19-25.

7. Parliament of Benin Republic. Law 2011-26 Prevention and repretion of violence against women. janv 9, 2012.

8. Abeid M, Muganyizi P, Massawe S, Mpembeni R, Darj E, Axemo P. Knowledge and attitude towards rape and child sexual abuse - a community-based cross-sectional study in Rural Tanzania. BMC Public Health. 2015;15:428.

9. Butun C, Yildirim A, ozer E, Yilmaz E, Aybuke Sari S. A Nonrandom Sample of 55 Sexual Abuse Cases in Sivas. Med Sci Monit. 2017;23(4):4360-5.

10. Jewkes R, Christofides N, Vetten L, Jina R, Sigsworth R, Loots L. Medico-Legal Findings, Legal Case Progression, and Outcomes in South African Rape Cases: Retrospective Review. PLoS Med. 2009;6(10):164-67.

11. Cisse CT, Niang MM, Sy AK, Faye EHO, Moreau J-C. Epidemioclinical, legal and cost aspects of he management of sexual abuse among minors in Dakar, Sénégal. J Gynécologie Obstétrique Biol Reprod. 2015;44(9):825-31.

12. Garcia-Moreno C, Jansen HAFM, Ellsberg M, Heise L, Watts CH, WHO Multi-country Study on Women's Health and Domestic Violence against Women Study Team. Prevalence of intimate partner violence: findings from the WHO multi-country study on women's health and domestic violence. Lancet Lond Engl. 2006;368(4):1260-9.

13. Patra AP, Shaha KK, Rayamane AP, Mohanty S. Victimology of alleged rape cases: A three year institution based cross sectional study. Indian J Forensic Community Med. 2015;2(4):203-8.

14. Pinheiro PS. World report on violence against children. Geneva: United Nations Publ; 2006. 364 p.

15. Watts C, Zimmerman C. Violence against women: global scope and magnitude. The Lancet. 2002;359(93):1232-7.

16. Soumah MM, Olendo GR, Ndiaye M, Sow ML. Sexual assault in Port-Gentil. Pan Afr Med J 2013;15:152.

17. Bah H, Ette HY, Soumah M, Diallo LL, Bah AA, Diallo $\mathrm{N}$, et al. Study of perpetrators of sexual violence in Conakry, Guinea. Rev Médecine Légale. 2011;2(2):54-8.

18. Delviovo CR, Bolsoni CC, Nazario NO, Coelho EBS. Characteristics of sexual violence against adolescent and adult women reported by the public health services in Santa Catarina State, Brazil. Cas Saude Publica. 2016 ; 33(6):1-12.

19. Niort F, Delteil C, Capasso F, Torrents R, Leonetti G, Piercecchi-Marti MD. Epidemioclinical study over 10 years of victims of rape received in consultation at the Marseille Institute for Forensic Medicine, CHU de Timone. Analyse de 592 cas de victime de viol. Rev Médecine Légale. 2014;5(2):62-9. 
20. Jina R, Jewkes R, Vetten L, Christofides N, Sigsworth R, Loots L. Genito-anal injury patterns and associated factors in rape survivors in an urban province of South Africa: a cross-sectional study. BMC Womens Health. 2015;15:29.

21. Burgos-Soto J, Orne-Gliemann J, Encrenaz G, Patassi A, Woronowski A, Kariyiare B, et al. Intimate partner sexual and physical violence among women in Togo, West Africa: prevalence, associated factors, and the specific role of HIV infection. Glob Health Action. 2014;7:23456.

22. Leye M, Ndiaye P, Ndiaye D, Seck I, Faye A, Tal Dia A. Epidemiological, clinical and forensic physical violence against women in Tambacounda (Senegal). Rev Epidemiol Santé Publique. 2017;65(3):189-96.
23. Essabar L, Khalqallah A, Benjelloun BS. Child sexual abuse: report of 311 cases with review of literature. Pan Afr Med J. $2015 ; 20: 47$

24. Menick DM. The problem of child victims of sexual abuse in Africa or the imbroglio of a double paradox: the example of Cameroon. Child Abuse Negl. 2001;25(1):109 $-21$.

25. Blake M de T, Drezett J, Vertamatti MA, Adami F, Valenti VE, Paiva AC, et al. Characteristics of sexual violence against adolescent girls and adult women. $B M C$ Womens Health. 2014;14(1):15. 